\title{
PENGARUH GETARAN PADA STRUKTUR BANGUNAN SATU TINGKAT AKIBAT GERAKAN MANUSIA
}

\author{
Dwi Catra Rimaza ${ }^{1}$, Daud Rachmat Wiyono ${ }^{2}$ \\ Jurusan Teknik Sipil, Fakultas Teknik, Universitas Kristen Maranatha, \\ hwiesiong@gmail.com
}

\begin{abstract}
ABSTRAK
Kriteria-kriteria yang harus diperhatikan dalam perencanaan suatu bangunan diantaranya adalah kekakuan, kekuatan, kestabilan, kelenturan dan keekonomisan. Ada satu kriteria yang seringkali terlupakan dalam perencanaan suatu bangunan, yaitu masalah getaran yang sangat berdampak terhadap kenyamanan penghuni bangunan itu sendiri. Analisis getaran dilakukan pada beberapa tipe pelat, balok induk, dan kolom dengan variasi pada ukuran dimensi. Pembahasan hanya dilakukan terhadap bangunan kantor, pusat perbelanjaan, dan tempat ibadah. Berbagai macam standar untuk kenyamanan manusia telah ada sejak bertahun-tahun lamanya, termasuk sejarah singkat perkembangan standar umum yang digunakan di Amerika Serikat dan Eropa. Batasan puncak percepatan untuk bangunan kantor, pusat perbelanjaan dan tempat ibadah berdasarkan panduan Steel Design Guide 11th Series "Floor Vibration due to Human Activity" adalah 0,5 \%; $1,5 \%$; dan $0,5 \%$. Analisis dilakukan berdasarkan panduan Steel Design Guide 11th Series "Floor Vibration due to Human Activity" di mana standar ini juga didasari oleh ISO 2631/1-1985 dan ISO 2631/2-1989 dan dengan bantuan program ETABS V9.5. Melalui program ini akan diperoleh periode getar dan berat struktur dari pemodelan bangunan yang dibuat. Disini diketahui dimensi minimum dari ketebalan pelat, balok induk dan kolom serta nilai perkiraan puncak percepatan getaran yang masih berada dalam batas toleransi sesuai dengan peraturan Steel Design Guide 11th Series..
\end{abstract}

Kata Kunci : Beban, Periode getar, Puncak percepatan.

\section{LATAR BELAKANG}

Seiring dengan meningkatnya jumlah penduduk di Indonesia serta perkembangan ilmu pengetahuan dalam bidang Teknik Sipil, kebutuhan pembangunan gedung bertingkat tinggi terus meningkat. Hal ini terjadi karena kebutuhan manusia Indonesia akan lahan tempat tinggal, perkantoran, tempat hiburan dan tempat ibadah semakin meningkat. Tetapi, kebutuhan manusia akan tempat tinggal, perkantoran, tempat hiburan dan tempat ibadah mengalami kendala keterbatasan lahan terutama di kota-kota besar sehingga manusia mencari alternatif solusi yaitu pembangunan gedung-gedung bertingkat tinggi. Dengan adanya gedung bertingkat tinggi, efektifitas penggunaan lahan menjadi meningkat. Tetapi perlu diingat bahwa semakin tinggi bangunan, semakin besar kemungkinan bangunan tersebut menimbulkan getaran. Oleh karena itu, dalam perencanaan pembangunan gedung bertingkat, perlu diperhatikan faktor-faktor yang mempengaruhi kenyamanan penghuni gedung tersebut.

Kenyamanan bagi penghuni gedung merupakan salah satu faktor yang harus diperhatikan dalam perencanaan suatu bangunan selain dari faktor kekakuan, kekuatan, kestabilan, daktilitas, dan keekonomisan. Namun, seringkali dalam perencanaan suatu 
bangunan faktor kenyamanan menjadi kurang atau bahkan tidak diperhatikan oleh para perencana sehingga menimbulkan ketidaknyamanan. Ketidaknyamanan ini disebabkan oleh terjadinya getaran pada elemen struktur yang melentur dan bergetar hingga mencapai di luar batas toleransi. Batasan kenyamanan ini memang berbeda-beda antara satu orang dengan orang lain. Suatu badan organisasi yang dikenal dengan "ISO" (International Standards Organization) membuat standar kriteria batasan bagi penghuni/pemakai gedung dan standar ini sudah dipergunakan oleh perencana bangunan di beberapa negara maju seperti Amerika Serikat, Australia, Inggris, dll.

Ada berbagai macam hal yang dapat menjadi penyebab terjadinya getaran pada bangunan, diantaranya :

1. Berasal dari dalam bangunan seperti peralatan mesin (elevators, escalators, trolli, mesin pompa, genset, dan lain-lain) serta aktifitas dari orang di dalam gedung (berjalan, berlari, meloncat, menari, dan lain-lain).

2. Berasal dari luar bangunan seperti lalu lintas kendaraan di jalan, kereta api, aktifitas pembangunan di sekitar gedung, ledakan bom, angin kencang dan gempa bumi.

Pada tulisan ini mencoba untuk menganalisis seberapa besar pengaruh getaran pada struktur bangunan bertingkat untuk beberapa tipe dimensi pelat lantai, balok induk, dan kolom beton bertulang yang sering dipergunakan dalam pembangunan serta jumlah lantai agar kemudian diketahui kelayakan pakai dimensi pelat tersebut sehingga mudah untuk diaplikasikan sesuai dengan kriteria batasan vibrasi dari standar "ISO".

\section{PERMASALAHAN}

Dengan melakukan analisis dinamik struktur untuk mengetahui seberapa besar pengaruh getaran pada struktur bangunan bertingkat dengan dimensi pelat, balok, dan kolom beton bertulang yang bervariasi setelah dibebani oleh beban mati dan beban hidup untuk kantor, pusat perbelanjaan, dan untuk tempat ibadah dengan menggunakan program ETABS V9.5. Kemudian menghitung perkiraan puncak percepatan struktur untuk dibandingkan dengan batas puncak percepatan. Selanjutnya menentukan kelayakan dimensi balok, kolom, dan pelat terhadap pengaruh getaran setelah dibebani oleh beban mati dan beban hidup menurut Pedoman Perencanaan Pembebanan untuk Rumah dan Gedung SKBI-1.3.53.1987.

\section{PEMBATASAN MASALAH}

Ruang lingkup yang dibahas dalam tugas akhir ini, antara lain :

Pengaruh Getaran Pada Struktur Bangunan Satu Tingkat Akibat Gerakan Manusia (Dwi Catra Rimaza, Daud Rachmat Wiyono) 
1. Sistem struktur yang ditinjau adalah sistem balok pelat

2. Sistem pelat beton bertulang yang ditinjau adalah pelat satu arah dan pelat dua arah

3. Analisis dilakukan menggunakan dimensi pelat, balok, dan kolom beton bertulang yang bervariasi

4. Analisis dilakukan pada bangunan bertingkat satu dan bertingkat dua

5. Analisis dilakukan dengan menggunakan program ETABS V9.5

6. Beban yang diperhitungkan untuk pelat lantai adalah beban mati tambahan sebesar $1,61865 \mathrm{kN} / \mathrm{m} 2$ dan beban hidup sebesar 2,4525 kN/m2 (kantor); 3,924 kN/m2 (pusat perbelanjaan); dan 3,924 kN/m2 (tempat ibadah)

7. Perhitungan dan pembahasan untuk penulangannya tidak dilakukan karena tidak mempengaruhi rumus yang dipakai

8. Mutu beton yang digunakan adalah $\mathrm{fc}^{\prime}=25 \mathrm{MPa}$

9. Peraturan yang dipergunakan adalah Standar Nasional Indonesia (SNI) 03-28472002 "Tata cara perencanaan struktur beton untuk bangunan gedung" dan Pedoman Perencanaan Pembebanan untuk Rumah dan Gedung SKBI-1.3.53.1987.

\section{EVALUASI HASIL PENGUJIAN}

\subsection{Standar untuk Kenyamanan Manusia [Steel Design Guide Series, 2003]}

\subsubsection{Respon Manusia Terhadap Gerakan Lantai}

Reaksi dari orang-orang yang merasakan vibrasi tergantung dari apa yang sedang mereka lakukan. Orang-orang di kantor atau di tempat tinggal mereka tidak menyukai vibrasi yang "nampak jelas" (puncak percepatan sekitar 0,5\% dari percepatan gravitasi, g), sedangkan orang-orang yang mengambil peran dalam sebuah aktifitas akan menerima vibrasi kurang lebih 10 kali lebih besar (5 $\% g$ atau lebih).

Orang-orang yang berada di lantai dansa, mengangkat beban di gedung aerobik atau gedung olahraga, atau berada di pusat perbelanjaan akan menerima vibrasi sekitar $1,5 \% \mathrm{~g}$. Kepekaan dalam setiap pekerjaan juga berbeda-beda sesuai dengan lamanya vibrasi dan jauhnya letak sumber vibrasi. Batasan limit untuk frekuensi vibrasi adalah diantara $4 \mathrm{~Hz}$ dan $8 \mathrm{~Hz}$. Di luar batasan tersebut, orang-orang menerima percepatan vibrasi yang lebih tinggi seperti yang terlihat pada Gambar 1. 


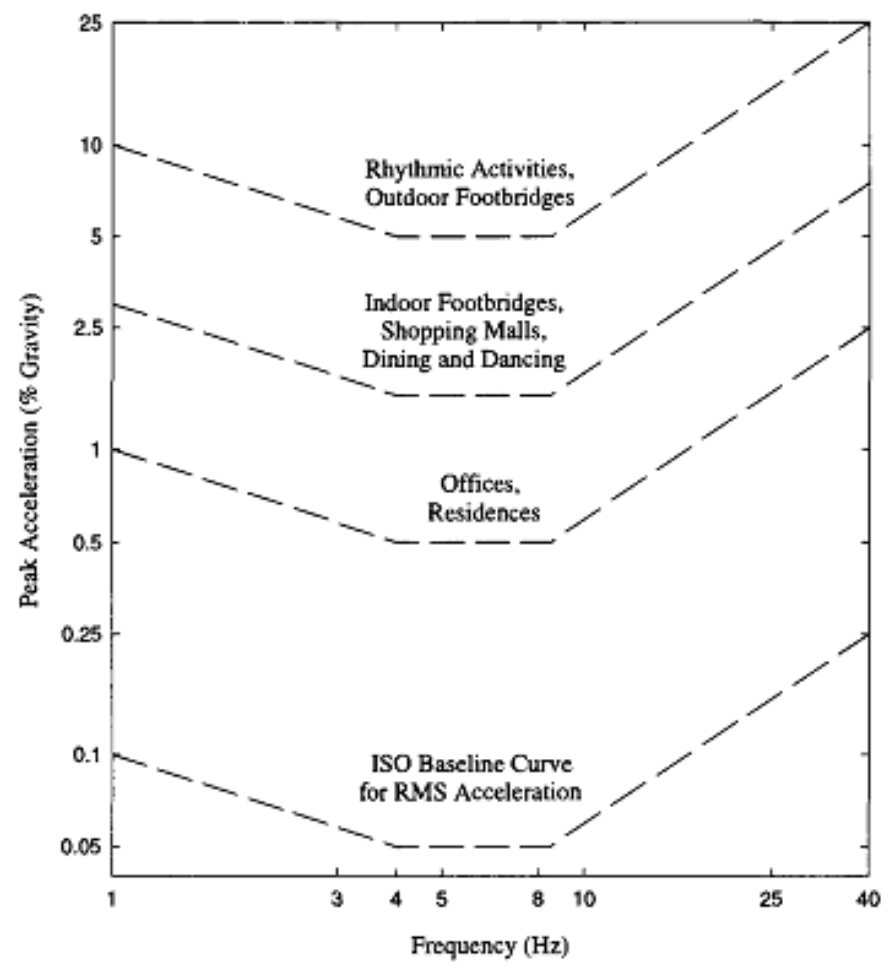

Gambar 1. Kurva puncak percepatan yang disarankan untuk kenyamanan manusia terhadap vibrasi menurut Allen dan Murray, 1993;

ISO 2631-2, 1989.

\subsubsection{Standar untuk Desain Struktur}

Berbagai macam standar untuk kenyamanan manusia telah ada sejak bertahun-tahun lamanya, termasuk sejarah singkat perkembangan standar umum yang digunakan di Amerika Serikat dan Eropa.

Bentuk dari fungsi respon sebuah resonansi :

$$
\frac{\mathrm{a}}{\mathrm{g}}=\frac{\mathrm{R} \cdot \alpha_{\mathrm{i}} \cdot \mathrm{P}}{\beta \cdot \mathrm{W}} \cdot \cos \left(2 \cdot \pi \cdot \mathrm{i} \cdot \mathrm{f}_{\mathrm{s}} \cdot \mathrm{t}\right)
$$

dimana :

$$
\begin{array}{ll}
\mathrm{a} / \mathrm{g} & =\text { rasio dari percepatan lantai dengan percepatan gravitasi } \\
\mathrm{R} & =\text { faktor reduksi } \\
\alpha_{\mathrm{i}} & =\text { koefisien dinamik }
\end{array}
$$




$$
\begin{array}{ll}
\beta & =\text { rasio modal damping (rasio redaman) } \\
\mathrm{W} & =\text { berat efektif lantai } \\
\mathrm{f}_{\mathrm{s}} & =\text { frekuensi langkah } \\
\mathrm{t} & =\text { waktu }
\end{array}
$$

Dimana $\mathrm{R}=0,7$ untuk jembatan penyeberangan dan 0,5 untuk struktur lantai dengan bentuk konfigurasi pelat dua arah. Faktor reduksi $\mathrm{R}$ masuk dalam persamaan karena gerakan resonansi tetap menyeluruh tidak dapat diterima untuk gerakan berjalan dan orang-orang tidak secara serempak berada di lokasi perpindahan bebanmaksimum.

Untuk desain, persamaan (2.4) dapat disederhanakan dengan memperkirakan/mendekatkan hubungan langkah antara koefisien $\operatorname{dinamik}\left(\alpha_{\mathrm{i}}\right)$ dengan frekuensi langkah $\left(\mathrm{f}_{\mathrm{s}}\right)$ yang dapat dilihat pada Gambar 2.7 dengan rumus $\alpha=0,83 \exp (-0,35$. f) . Substitusi ini membuat rumus standar desain disederhanakan menjadi :

$$
\frac{a_{p}}{g} \leq \frac{P_{o} \cdot \exp \left(-0,35 \cdot f_{n}\right)}{\beta \cdot W} \leq \frac{a_{o}}{g}
$$

dimana :

$$
\begin{array}{ll}
\mathrm{a}_{\mathrm{p}} / \mathrm{g} & =\text { perkiraan puncak percepatan } \\
\mathrm{a}_{\mathrm{o}} / \mathrm{g} & =\text { puncak percepatan } \\
\mathrm{f}_{\mathrm{n}} & =\text { frekuensi natural struktur } \\
\mathrm{P}_{\mathrm{o}} & =\text { gaya tetap }(0,29 \mathrm{KN} \text { untuk lantai dan } 0,41 \mathrm{KN} \text { untuk jembatan }) \\
\beta & =\text { rasio redaman } \\
\mathrm{W} & =\text { berat efektif struktur }
\end{array}
$$

dimana nilai $\mathrm{P}_{\mathrm{o}}, \beta$ dan limit $\mathrm{a}_{\mathrm{o}} / \mathrm{g}$ dapat dilihat pada Tabel 1. Pembilang $\mathrm{P}_{\mathrm{o}} \exp (-$ $0,35 \cdot f_{n}$ ) dalam persamaan (2) mewakili gaya harmonik efektif akibat gerakan berjalan di mana hasil dalam respon resonansi pada frekuensi natural struktur, $f_{n}$. Persamaan (2) adalah standar desain yang sama yang diajukan oleh Allen dan Murray (1993), hanya saja formatnya berbeda. 


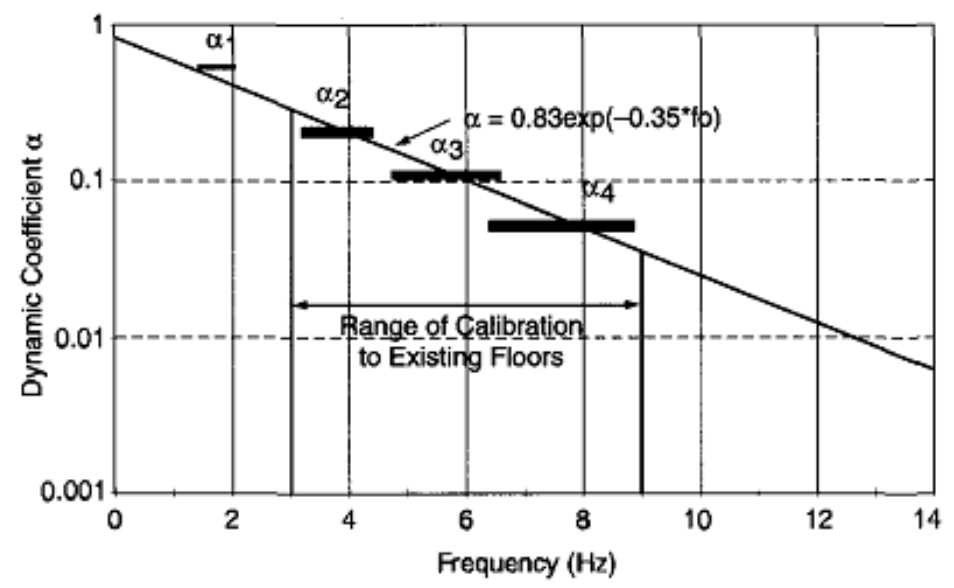

Gambar 2. Grafik koefisien dinamik $(\alpha)$ terhadap frekuensi [Steel Design Guide Series, 2003].

Tabel 1. Nilai parameter Po, $\beta$, dan limit $\mathbf{a}_{\mathbf{o}} / \mathbf{g}$ [Steel Design Guide Series, 2003].

\begin{tabular}{|c|c|c|c|}
\hline JENIS & $\begin{array}{c}\text { GAYA } \\
\text { TETAP } \\
\text { Po }(\mathbf{K N})\end{array}$ & $\begin{array}{c}\text { RASIO } \\
\text { REDAMAN } \\
\beta\end{array}$ & $\begin{array}{c}\text { LIMIT PERCEPATAN } \\
\mathrm{a}_{\mathbf{0}} / \mathrm{g} \times 100 \%\end{array}$ \\
\hline $\begin{array}{l}\text { Kantor, tempat tinggal, tempat } \\
\text { ibadah }\end{array}$ & 0,29 & $0,02-0,05$ & $0,5 \%$ \\
\hline Pusat perbelanjaan & 0,29 & 0,02 & $1,5 \%$ \\
\hline $\begin{array}{l}\text { Jembatan penyeberangan (dalam } \\
\text { ruangan) }\end{array}$ & 0,41 & 0,01 & $1,5 \%$ \\
\hline $\begin{array}{l}\text { Jembatan penyeberangan (luar } \\
\text { ruangan) }\end{array}$ & 0,41 & 0,01 & $5,0 \%$ \\
\hline \multicolumn{4}{|c|}{$\begin{array}{l}\beta=0,02 \text { untuk pelat dengan komponen non-struktur (komponen partisi, pipa-pipa } \\
\text { saluranpembatas) yang terdapat pada area kerja terbuka dan tempat ibadah. } \\
\beta=0,03 \text { untuk pelat dengan komponen non-struktur dan perabotan, } \\
\text { tetapi dengan hanya } \\
\text { komponen partisi yang kecil, tipikal dari banyak modul area kantor. } \\
\beta=0,05 \text { untuk partisi tinggi penuh diantara pelat. }\end{array}$} \\
\hline
\end{tabular}

\section{STUDI KASUS DAN PEMBAHASAN}

\subsection{Studi Kasus}

\section{Data Struktur}

Struktur bangunan yang akan dimodelkan memiliki data umum sebagai berikut :

Tinggi lantai $=4 \mathrm{~m}=4000 \mathrm{~mm}$

Jarak antar kolom (as ke as) :

$$
\text { Arah } \mathrm{x}=8 \mathrm{~m}=8000 \mathrm{~mm}
$$


Arah y $\quad=8 \mathrm{~m}=8000 \mathrm{~mm}$

\subsubsection{Data Material}

Struktur pelat, balok, dan kolom merupakan struktur beton bertulang dengan data material sebagai berikut :

a. Material Beton Bertulang :

1. Kuat tekan beton, $\mathrm{f}_{\mathrm{c}}{ }^{\prime}=25 \mathrm{MPa}$

2. Berat jenis beton, $\gamma_{\mathrm{w}} \quad=2,4 \times 10^{-5} \mathrm{~N} / \mathrm{mm}^{3}$

3. Massa jenis beton, $\gamma_{\mathrm{m}}=2,4 \times 10^{-9} \mathrm{~N} / \mathrm{mm}^{3}$

4. Modulus elastisitas beton, $\mathrm{E}_{\mathrm{c}}=4700 \sqrt{\mathrm{f}_{\mathrm{c}}{ }^{\prime}}=23500 \mathrm{MPa}$

b. Material Tulangan Non-prategang Balok, Kolom dan Pelat :

1. Kuat leleh tulangan non-prategang (lentur), $\mathrm{f}_{\mathrm{y}}=400 \mathrm{MPa}$

2. Kuat leleh tulangan geser, $\mathrm{f}_{\mathrm{ys}} \quad=400 \mathrm{MPa}$

3. Modulus elastisitas tulangan non-prategang, $\mathrm{E}_{\mathrm{s}} \quad=200000 \mathrm{MPa}$

4. Cover minimumberdasarkan SNI 2002 :

Pelat

$=20 \mathrm{~mm}$

Balok dan kolom

$=40 \mathrm{~mm}$

\subsubsection{Data Komponen Struktur}

Komponen struktur terdiri dari balok, kolom, dan pelat lantai, seperti pada Gambar 3, Gambar 4, dan Gambar 5. Pada permodelan struktur, digunakan dimensi balok, pelat dan kolom dengan ukuran-ukuran sebagai berikut :

1. Balok Induk untuk Sistem Pelat Satu Arah dan Dua Arah :
a. Ukuran $300 \times 500 \mathrm{~mm}$
b. Ukuran $300 \times 600 \mathrm{~mm}$
c. Ukuran $300 \times 700 \mathrm{~mm}$

2. Balok Anak

a. Ukuran $250 \times 550 \mathrm{~mm}$, untuk sistem pelat satu arah

b. Ukuran 250 x $500 \mathrm{~mm}$, untuk sistem pelat dua arah

3. Pelat lantai

a. Sistem Pelat Satu Arah :

1) Tebal $120 \mathrm{~mm}$ 
2) Tebal $140 \mathrm{~mm}$

3) Tebal $160 \mathrm{~mm}$

b. Sistem Pelat Dua Arah :

1) Tebal $80 \mathrm{~mm}$

2) Tebal $100 \mathrm{~mm}$

3) Tebal $120 \mathrm{~mm}$

4. Kolom Sistem Pelat Satu Arah dan Dua Arah :
a. Ukuran $400 \times 400 \mathrm{~mm}$
b. Ukuran $500 \times 500 \mathrm{~mm}$
c. Ukuran $600 \times 600 \mathrm{~mm}$

Dimensi-dimensi komponen struktur di atas, dapat dilihat pada Tabel 2.

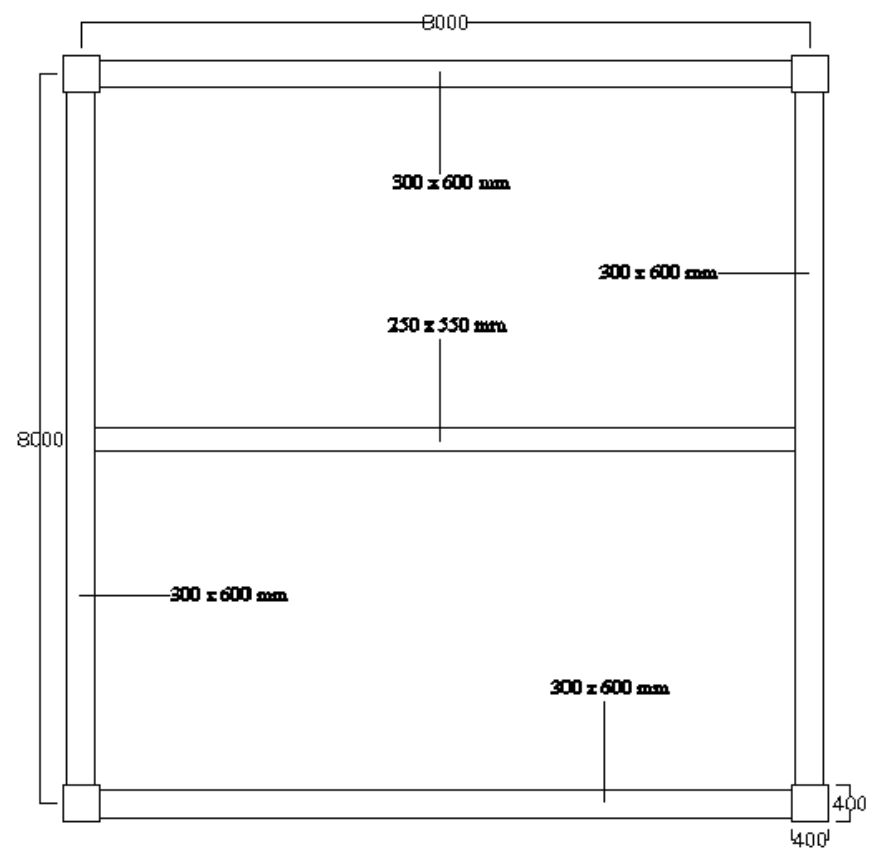

Gambar 3. Denah Struktur Pelat Satu Arah. 


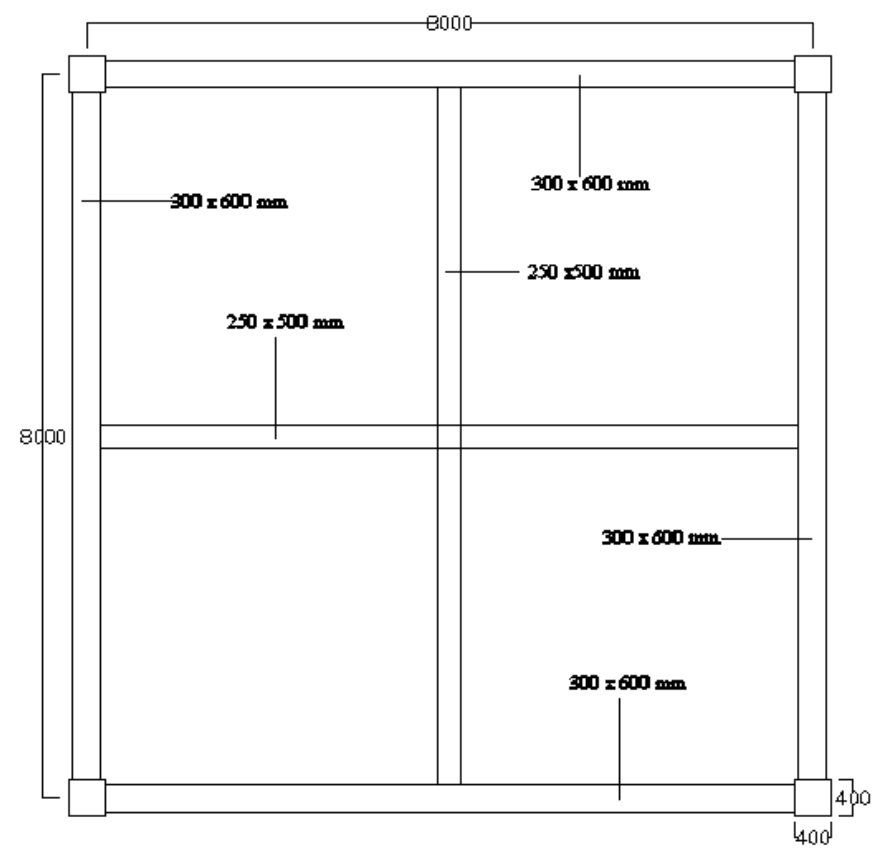

Gambar 4. Denah Struktur Pelat Dua Arah.

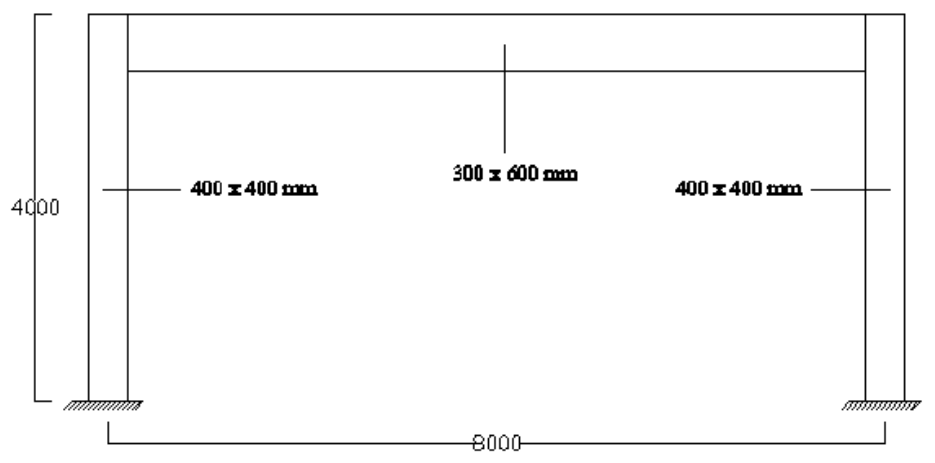

Gambar 5. Potongan Melintang Denah 1 Lantai.

Tabel 2. Tabel Dimensi Komponen Struktur

\begin{tabular}{|c|c|c|}
\hline & \multicolumn{2}{|c|}{ SISTEM PELAT } \\
\hline & SATU ARAH & DUA ARAH \\
\hline \multirow{3}{*}{$\begin{array}{l}\text { DIMENSI BALOK } \\
\text { INDUK }\end{array}$} & $300 \times 500 \mathrm{~mm}$ & $300 \times 500 \mathrm{~mm}$ \\
\hline & $300 \times 600 \mathrm{~mm}$ & $300 \times 600 \mathrm{~mm}$ \\
\hline & $300 \times 700 \mathrm{~mm}$ & $300 \times 700 \mathrm{~mm}$ \\
\hline
\end{tabular}




\begin{tabular}{|c|c|c|}
\hline \multicolumn{3}{|c|}{ Tabel 2. Lanjutan. } \\
\hline \multirow{2}{*}{ DIMENSI BALOK ANAK } & $250 \times 550 \mathrm{~mm}$ & $250 \times 500 \mathrm{~mm}$ \\
\hline \multirow{2}{*}{ TEBAL PELAT } & $120 \mathrm{~mm}$ & $80 \mathrm{~mm}$ \\
\cline { 2 - 3 } & $140 \mathrm{~mm}$ & $100 \mathrm{~mm}$ \\
\cline { 2 - 3 } & $160 \mathrm{~mm}$ & $120 \mathrm{~mm}$ \\
\hline \multirow{2}{*}{ DIMENSI KOLOM } & $400 \times 400 \mathrm{~mm}$ & $400 \times 400 \mathrm{~mm}$ \\
\cline { 2 - 3 } & $500 \times 500 \mathrm{~mm}$ & $500 \times 500 \mathrm{~mm}$ \\
\cline { 2 - 3 } & $600 \times 600 \mathrm{~mm}$ & $600 \times 600 \mathrm{~mm}$ \\
\hline
\end{tabular}

\subsubsection{Data Pembebanan}

Struktur bangunan ini hanya akan menerima beban statik gravitasi diantaranya sebagai berikut :

1. Beban Mati (berat sendiri struktur), DL (self-weight)

Berat sendiri dari seluruh komponen struktur telah dihitung secara internal di dalam program ETABS V9.5, dengan berat jenis beton yang telah ditentukan yaitu sebesar $2,4 \times 10^{-5} \mathrm{~N} / \mathrm{mm}^{3}\left(2400 \mathrm{~kg} / \mathrm{m}^{3}\right)$.

2. Beban Mati Tambahan, SDL (super impose dead load)

Beban mati tambahan diakibatkan oleh beban gravitasi dari beban tidak bergerak selain berat sendiri struktur. Pada sruktur bangunan ini, beban mati tambahan diakibatkan oleh beban plafond dan penggantung, spesi, ubin, dan pasir urug.
a. Berat sendiri plafond \& penggantung
$=0,17658 \mathrm{kN} / \mathrm{m}^{2}$
b. Berat sendiri spesi $(\mathrm{t}=30 \mathrm{~mm})$
$=0,61803 \mathrm{kN} / \mathrm{m}^{2}$
c. Berat sendiri ubin $(\mathrm{t}=20 \mathrm{~mm})$
$=0,47088 \mathrm{kN} / \mathrm{m}^{2}$
d. Berat sendiri pasir urug $(\mathrm{t}=20 \mathrm{~mm})$
$=0,35316 \mathrm{kN} / \mathrm{m}^{2}+$
Total
$=1,61865 \mathrm{kN} / \mathrm{m}^{2}$

3. Beban Hidup, LL (live load)

Beban hidup diakibatkan oleh beban gravitasi yang berasal dari benda bergerak. Pada struktur bangunan yang akan didesain dan dianalisis ini, 
ketentuan beban hidup diambil berdasarkan pada Pedoman Perencanaan Pembebanan untuk Rumah dan Gedung SKBI-1.3.53.1987 yaitu :
a. Beban hidup pada lantai kantor
$=2,4525 \mathrm{kN} / \mathrm{m}^{2}$
b. Beban hidup pada lantai pusat perbelanjaan
$=3,924 \mathrm{kN} / \mathrm{m}^{2}$
c. Beban hidup pada lantai tempat ibadah
$=3,924 \mathrm{kN} / \mathrm{m}^{2}$

\subsubsection{Kombinasi Pembebanan}

Kombinasi pembebanan yang digunakan dalam perhitungan dalam kondisi layan adalah 1DL + 1SDL + 1LL. Pembahasan: Setelah dilakukan pemodelan struktur dengan menggunakan ETABS V9.5, didapatkan nilai-nilai $\mathrm{a}_{\mathrm{p}} / \mathrm{g}(\%)$ (perkiraan puncak percepatan) yang dihitung setelah melalui analisis pada struktur bangunan tersebut.

\subsubsection{Bangunan SatuTingkat}

1. Pelat SatuArah

a. Variasi pada Tebal Pelat (Model 1)

Tabel 3. Hasil Analisis padaBangunan Satu Lantai Sistem Pelat Satu Arah, Variasi Tebal Pelat.

\begin{tabular}{|c|c|c|c|c|c|c|c|c|c|}
\hline & \multicolumn{9}{|c|}{ MODEL 1} \\
\hline $\begin{array}{l}\text { Balok Induk } \\
(\mathrm{mm})\end{array}$ & \multicolumn{9}{|c|}{$300 \times 600$} \\
\hline $\begin{array}{l}\text { Balok Anak } \\
(\mathrm{mm})\end{array}$ & \multicolumn{9}{|c|}{$250 \times 550$} \\
\hline Kolom (mm) & \multicolumn{9}{|c|}{$500 \times 500$} \\
\hline $\begin{array}{l}\text { Jumlah } \\
\text { Lantai }\end{array}$ & \multicolumn{9}{|c|}{1} \\
\hline $\begin{array}{l}\text { Beban Mati } \\
\left(\mathrm{kN} / \mathrm{m}^{2}\right)\end{array}$ & \multicolumn{9}{|c|}{1,61865} \\
\hline $\begin{array}{l}\text { Tebal Pelat } \\
(\mathbf{m m})\end{array}$ & \multicolumn{3}{|c|}{120} & \multicolumn{3}{|c|}{140} & \multicolumn{3}{|c|}{160} \\
\hline $\begin{array}{l}\text { Beban Hidup } \\
\left(\mathrm{kN} / \mathrm{m}^{2}\right)\end{array}$ & $2,4525^{\text {(a) }}$ & $3,924^{(\mathrm{b})}$ & $3,924^{(\mathrm{c})}$ & $2,4525^{\text {(a) }}$ & $3,924^{(\mathfrak{b})}$ & $3,924^{(\mathrm{c})}$ & $2,4525^{\text {(a) }}$ & $3,924^{(\mathrm{b})}$ & $3,924^{(\mathrm{c})}$ \\
\hline $\begin{array}{l}\text { Periode } \\
\text { Getar }\end{array}$ & 0.199 & 0.199 & 0.199 & 0.206 & 0.206 & 0.206 & 0.214 & 0.214 & 0.214 \\
\hline Frekuensi & 5.031 & 5.031 & 5.031 & 4.843 & 4.843 & 4.843 & 4.675 & 4.675 & 4.675 \\
\hline Berat $(\mathrm{kN})$ & 428.321 & 428.321 & 428.321 & 458.478 & 458.478 & 458.478 & 488.634 & 488.634 & 488.634 \\
\hline $\mathbf{a}_{\mathrm{p}} / \mathbf{g}$ & 0.004 & 0.006 & 0.006 & 0.004 & 0.006 & 0.006 & 0.004 & 0.006 & 0.006 \\
\hline$a_{p} / g(\%)$ & 0.388 & 0.582 & 0.582 & 0.387 & 0.581 & 0.581 & 0.385 & 0.578 & 0.578 \\
\hline
\end{tabular}

Keterangan : (a) : Beban hidup untuk kantor 
(b) : Beban hidup untuk pusat perbelanjaan

(c) : Beban hidup untuk tempat ibadah

b. Variasi pada Ukuran Dimensi Balok Induk

Tabel 4. Hasil Analisis pada Bangunan Satu Tingkat Sistem Pelat Satu Arah, Variasi Dimensi Balok Induk.

\begin{tabular}{|c|c|c|c|c|c|c|c|c|c|}
\hline & \multicolumn{9}{|c|}{ MODEL 2} \\
\hline $\begin{array}{l}\text { Tebal Pelat } \\
(\mathrm{mm})\end{array}$ & \multicolumn{9}{|c|}{160} \\
\hline $\begin{array}{l}\text { Balok Anak } \\
(\mathrm{mm})\end{array}$ & \multicolumn{9}{|c|}{$250 \times 550$} \\
\hline Kolom (mm) & \multicolumn{9}{|c|}{$500 \times 500$} \\
\hline $\begin{array}{l}\text { Jumlah } \\
\text { Lantai }\end{array}$ & \multicolumn{9}{|c|}{1} \\
\hline $\begin{array}{l}\text { Beban Mati } \\
\left(\mathrm{kN} / \mathrm{m}^{2}\right)\end{array}$ & \multicolumn{9}{|c|}{1,61865} \\
\hline $\begin{array}{l}\text { Balok Induk } \\
\text { (mm) }\end{array}$ & \multicolumn{3}{|c|}{$300 \times 500$} & \multicolumn{3}{|c|}{$300 \times 600$} & \multicolumn{3}{|c|}{$300 \times 700$} \\
\hline $\begin{array}{l}\text { Beban Hidup } \\
\left(\mathrm{kN} / \mathrm{m}^{2}\right)\end{array}$ & $2,4525^{\text {(a) }}$ & $3,924^{(b)}$ & $3,924^{(\mathrm{c})}$ & $2,4525^{\text {(a) }}$ & $3,924^{(b)}$ & $3,924^{(\mathrm{c})}$ & $2,4525^{\text {(a) }}$ & $3,924^{(b)}$ & $3,924^{(\mathrm{c})}$ \\
\hline Periode Getar & 0.228 & 0.228 & 0.228 & 0.214 & 0.214 & 0.214 & 0.205 & 0.205 & 0.205 \\
\hline Frekuensi & 4.389 & 4.389 & 4.389 & 4.675 & 4.675 & 4.675 & 4.886 & 4.886 & 4.886 \\
\hline Berat $(\mathrm{kN})$ & 467.430 & 467.430 & 467.430 & 488.63 & 488.63 & 488.63 & 509.84 & 509.84 & 509.84 \\
\hline$a_{p} / g$ & 0.004 & 0.007 & 0.007 & 0.004 & 0.006 & 0.006 & 0.003 & 0.005 & 0.005 \\
\hline$a_{p} / g(\%)$ & 0.445 & 0.668 & 0.668 & 0.385 & 0.578 & 0.578 & 0.343 & 0.514 & 0.514 \\
\hline
\end{tabular}

Keterangan : (a) : Beban hidup untuk kantor

(b) : Beban hidup untuk pusat perbelanjaan

(c) : Beban hidup untuk tempat ibadah

c. Variasi pada Ukuran Dimensi Kolom

Tabel 5. Hasil Analisis pada Bangunan Satu Tingkat Sistem Pelat Satu Arah, Variasi Dimensi Kolom.

\begin{tabular}{|l|c|}
\hline & MODEL 3 \\
\hline $\begin{array}{l}\text { Balok Induk } \\
(\mathbf{m m})\end{array}$ & 300 X600 \\
\hline $\begin{array}{l}\text { Balok Anak } \\
(\mathbf{m m})\end{array}$ & 250 X550 \\
\hline $\begin{array}{l}\text { Tebal Pelat } \\
(\mathbf{m m})\end{array}$ & 160 \\
\hline $\begin{array}{l}\text { Jumlah } \\
\text { Lantai }\end{array}$ & 1 \\
\hline
\end{tabular}

Pengaruh Getaran Pada Struktur Bangunan Satu Tingkat Akibat Gerakan Manusia 


\begin{tabular}{|c|c|c|c|c|c|c|c|c|c|}
\hline \multicolumn{10}{|c|}{ Tabel 5. Lanjutan. } \\
\hline $\begin{array}{l}\text { Beban Mati } \\
\left(\mathrm{kN} / \mathrm{m}^{2}\right)\end{array}$ & \multicolumn{9}{|c|}{1,61865} \\
\hline Kolom (mm) & \multicolumn{3}{|c|}{$400 \times 400$} & \multicolumn{3}{|c|}{$500 \times 500$} & \multicolumn{3}{|c|}{$600 \times 600$} \\
\hline $\begin{array}{l}\text { Beban Hidup } \\
\left(\mathrm{kN} / \mathrm{m}^{2}\right)\end{array}$ & $2,4525^{\text {(a) }}$ & $3,924^{(b)}$ & $3,924^{(c)}$ & $2,4525^{\text {(a) }}$ & $3,924^{(\text {b) }}$ & $3,924^{(\mathrm{c})}$ & $2,4525^{\text {(a) }}$ & $3,924^{(b)}$ & $3,924^{(\mathrm{c})}$ \\
\hline $\begin{array}{l}\text { Periode } \\
\text { Getar }\end{array}$ & 0.289 & 0.289 & 0.289 & 0.214 & 0.214 & 0.214 & 0.171 & 0.171 & 0.171 \\
\hline Frekuensi & 3.456 & 3.456 & 3.456 & 4.675 & 4.675 & 4.675 & 5.837 & 5.837 & 5.837 \\
\hline Berat $(\mathrm{kN})$ & 456.404 & 456.404 & 456.404 & 488.634 & 488.634 & 488.634 & 528.404 & 528.404 & 528.404 \\
\hline$a_{p} / g$ & 0.006 & 0.009 & 0.009 & 0.004 & 0.006 & 0.006 & 0.002 & 0.004 & 0.004 \\
\hline$a_{p} / g(\%)$ & 0.632 & 0.948 & 0.948 & 0.385 & 0.578 & 0.578 & 0.237 & 0.356 & 0.356 \\
\hline
\end{tabular}

Keterangan : (a) : Beban hidup untuk kantor

(b) : Beban hidup untuk pusat perbelanjaan

(c) : Beban hidup untuk tempat ibadah

2. Pelat 2 Arah

a. Variasi pada Tebal Pelat

Tabel 6. Hasil Analisis pada Bangunan Satu TingkatSistem Pelat Dua Arah, Variasi Tebal Pelat.

\begin{tabular}{|c|c|c|c|c|c|c|c|c|c|}
\hline & \multicolumn{9}{|c|}{ MODEL 1} \\
\hline $\begin{array}{l}\text { Balok Induk } \\
(\mathrm{mm})\end{array}$ & \multicolumn{9}{|c|}{$300 \times 600$} \\
\hline $\begin{array}{l}\text { Balok Anak } \\
(\mathrm{mm})\end{array}$ & \multicolumn{9}{|c|}{$250 \times 500$} \\
\hline Kolom (mm) & \multicolumn{9}{|c|}{$500 \times 500$} \\
\hline $\begin{array}{l}\text { Jumlah } \\
\text { Lantai }\end{array}$ & \multicolumn{9}{|c|}{1} \\
\hline $\begin{array}{l}\text { Beban Mati } \\
\left(\mathrm{kN} / \mathrm{m}^{2}\right)\end{array}$ & \multicolumn{9}{|c|}{1,61865} \\
\hline $\begin{array}{l}\text { Tebal Pelat } \\
(\mathrm{mm})\end{array}$ & \multicolumn{3}{|c|}{80} & \multicolumn{3}{|c|}{100} & \multicolumn{3}{|c|}{120} \\
\hline $\begin{array}{l}\text { Beban Hidup } \\
\left(\mathrm{kN} / \mathrm{m}^{2}\right)\end{array}$ & $2,4525^{\text {(a) }}$ & $3,924^{(\mathrm{b})}$ & $3,924^{(\mathrm{c})}$ & $2,4525^{\text {(a) }}$ & $3,924^{(\mathrm{b})}$ & $3,924^{(\mathrm{c})}$ & $2,4525^{(\mathrm{a})}$ & $3,924^{(\mathrm{b})}$ & $3,924^{(\mathrm{c})}$ \\
\hline $\begin{array}{l}\text { Periode } \\
\text { Getar }\end{array}$ & 0.188 & 0.188 & 0.188 & 0.196 & 0.196 & 0.196 & 0.204 & 0.204 & 0.204 \\
\hline Frekuensi & 5.309 & 5.309 & 5.309 & 5.090 & 5.090 & 5.090 & 4.895 & 4.895 & 4.895 \\
\hline Berat (kN) & 389.211 & 389.211 & 389.211 & 419.368 & 419.368 & 419.368 & 449.525 & 449.525 & 449.525 \\
\hline$a_{p} / g$ & 0.004 & 0.006 & 0.006 & 0.004 & 0.006 & 0.006 & 0.004 & 0.006 & 0.006 \\
\hline$a_{p} / g(\%)$ & 0.387 & 0.581 & 0.581 & 0.388 & 0.582 & 0.582 & 0.388 & 0.582 & 0.582 \\
\hline
\end{tabular}

Keterangan : (a) : Beban hidup untuk kantor

(b) : Beban hidup untuk pusat perbelanjaan 
(c) : Beban hidup untuk tempat ibadah

b. Variasi pada Ukuran Dimensi Balok Induk

Tabel 7. Hasil Analisis pada Bangunan Satu Tingkat Sistem Pelat Dua Arah, Variasi Dimensi Balok Induk.

\begin{tabular}{|c|c|c|c|c|c|c|c|c|c|}
\hline & \multicolumn{9}{|c|}{ MODEL 2} \\
\hline $\begin{array}{l}\text { Tebal Pelat } \\
(\mathrm{mm})\end{array}$ & \multicolumn{9}{|c|}{120} \\
\hline $\begin{array}{l}\text { Balok Anak } \\
(\mathrm{mm})\end{array}$ & \multicolumn{9}{|c|}{$250 \times 500$} \\
\hline Kolom (mm) & \multicolumn{9}{|c|}{$500 \times 500$} \\
\hline $\begin{array}{l}\text { Jumlah } \\
\text { Lantai }\end{array}$ & \multicolumn{9}{|c|}{1} \\
\hline $\begin{array}{l}\text { Beban Mati } \\
\left(\mathrm{kN} / \mathrm{m}^{2}\right)\end{array}$ & \multicolumn{9}{|c|}{1,61865} \\
\hline $\begin{array}{l}\text { Balok Induk } \\
(\mathrm{mm})\end{array}$ & \multicolumn{3}{|c|}{$300 \times 500$} & \multicolumn{3}{|c|}{$300 \times 600$} & \multicolumn{3}{|c|}{$300 \times 700$} \\
\hline $\begin{array}{l}\text { Beban Hidup } \\
\left(\mathrm{kN} / \mathrm{m}^{2}\right)\end{array}$ & $2,4525^{\text {(a) }}$ & $3,924^{(b)}$ & $3,924^{(c)}$ & $2,4525^{\text {(a) }}$ & $3,924^{(\mathrm{b})}$ & $3,924^{(c)}$ & $2,4525^{\text {(a) }}$ & $3,924^{(b)}$ & $3,924^{(\mathrm{c})}$ \\
\hline $\begin{array}{l}\text { Periode } \\
\text { Getar }\end{array}$ & 0.217 & 0.217 & 0.217 & 0.204 & 0.204 & 0.204 & 0.204 & 0.204 & 0.204 \\
\hline Frekuensi & 4.607 & 4.607 & 4.607 & 4.895 & 4.895 & 4.895 & 4.894 & 4.894 & 4.894 \\
\hline Berat $(\mathbf{k N})$ & 428.321 & 428.321 & 428.321 & 449.525 & 449.525 & 449.525 & 428.321 & 428.321 & 428.321 \\
\hline$a_{p} / g$ & 0.005 & 0.007 & 0.007 & 0.004 & 0.006 & 0.006 & 0.004 & 0.006 & 0.006 \\
\hline$a_{p} / g(\%)$ & 0.450 & 0.675 & 0.675 & 0.388 & 0.582 & 0.582 & 0.407 & 0.610 & 0.610 \\
\hline
\end{tabular}

Keterangan : (a) : Beban hidup untuk kantor

(b) : Beban hidup untuk pusat perbelanjaan

(c) : Beban hidup untuk tempat ibadah

c. Variasi pada Ukuran Dimensi Kolom

Tabel 8. Hasil Analisis pada Bangunan Satu Tingkat Sistem Pelat DuaArah, Variasi Dimensi Kolom.

\begin{tabular}{|c|c|c|c|}
\hline & \multicolumn{3}{|c|}{ MODEL 3} \\
\hline $\begin{array}{l}\text { Balok Induk } \\
(\mathrm{mm})\end{array}$ & \multicolumn{3}{|c|}{$300 \times 600$} \\
\hline $\begin{array}{l}\text { Balok Anak } \\
(\mathrm{mm})\end{array}$ & \multicolumn{3}{|c|}{$20 \times 500$} \\
\hline $\begin{array}{l}\text { Tebal Pelat } \\
(\mathrm{mm})\end{array}$ & \multicolumn{3}{|c|}{120} \\
\hline $\begin{array}{l}\text { Jumlah } \\
\text { Lantai }\end{array}$ & \multicolumn{3}{|c|}{1} \\
\hline $\begin{array}{l}\text { Beban Mati } \\
\left(\mathrm{kN} / \mathrm{m}^{2}\right)\end{array}$ & \multicolumn{3}{|c|}{1,61865} \\
\hline Kolom (mm) & $400 \times 400$ & $500 \times 500$ & $600 \times 600$ \\
\hline
\end{tabular}

Pengaruh Getaran Pada Struktur Bangunan Satu Tingkat Akibat Gerakan Manusia (Dwi Catra Rimaza, Daud Rachmat Wiyono) 


\begin{tabular}{|l|c|c|c|c|c|c|c|c|c|}
\hline \multicolumn{1}{|c|}{ Tabel 8. Lanjutan. } \\
\hline $\begin{array}{l}\text { Beban Hidup } \\
\mathbf{k N N}^{\mathbf{2}} \mathbf{)}\end{array}$ & $2,4525^{(\mathrm{a})}$ & $3,924^{(\mathrm{b})}$ & $3,924^{(\mathrm{c})}$ & $2,4525^{(\mathrm{a})}$ & $3,924^{(\mathrm{b})}$ & $3,924^{(\mathrm{c})}$ & $2,4525^{(\mathrm{a})}$ & $3,924^{(\mathrm{b})}$ & $3,924^{(\mathrm{c})}$ \\
\hline $\begin{array}{l}\text { Periode } \\
\text { Getar }\end{array}$ & 0.276 & 0.276 & 0.276 & 0.204 & 0.204 & 0.204 & 0.164 & 0.164 & 0.164 \\
\hline Frekuensi & 3.626 & 3.626 & 3.626 & 4.895 & 4.895 & 4.895 & 6.099 & 6.099 & 6.099 \\
\hline Berat (kN) & 417.295 & 417.295 & 417.295 & 449.525 & 449.525 & 449.525 & 489.29 & 489.294 & 489.29 \\
\hline $\mathbf{a}_{\mathbf{p}} / \mathbf{g}$ & 0.007 & 0.010 & 0.010 & 0.004 & 0.006 & 0.006 & 0.002 & 0.004 & 0.004 \\
\hline $\mathbf{a}_{\mathbf{p}} / \mathbf{g}(\mathbf{\%})$ & 0.651 & 0.977 & 0.977 & 0.388 & 0.581 & 0.581 & 0.234 & 0.351 & 0.351 \\
\hline
\end{tabular}

Keterangan : (a) : Beban hidup untuk kantor

(b) : Beban hidup untuk pusat perbelanjaan

(c) : Beban hidup untuk tempat ibadah

Dari seluruh pembahasan di atas, didapatkan hasil seperti pada Tabel 3.18 berikut

Tabel 9. Tabel Hasil Analisis dan Pembahasan.

\begin{tabular}{|c|c|c|c|c|c|}
\hline Lantai & $\begin{array}{c}\text { Sistem } \\
\text { Pelat }\end{array}$ & Bangunan & $\begin{array}{l}\text { Pelat } \\
\text { (mm) }\end{array}$ & $\begin{array}{l}\text { Balok } \\
(\mathbf{m m})\end{array}$ & $\begin{array}{c}\text { Kolom } \\
(\mathrm{mm})\end{array}$ \\
\hline \multirow{6}{*}{1} & \multirow{3}{*}{ Searah } & Kantor & 120 & $300 \times 500$ & $500 \times 500$ \\
\hline & & Pusat Perbelanjaan & 120 & $300 \times 500$ & $400 \times 400$ \\
\hline & & Tempat Ibadah & - & - & $600 \times 600$ \\
\hline & \multirow{3}{*}{ Dua Arah } & Kantor & 80 & $300 \times 500$ & $500 \times 500$ \\
\hline & & Pusat Perbelanjaan & 80 & $300 \times 500$ & $400 \times 400$ \\
\hline & & Tempat Ibadah & - & - & $600 \times 600$ \\
\hline \multirow{6}{*}{2} & \multirow{3}{*}{ Searah } & Kantor & 120 & $300 \times 600$ & $500 \times 500$ \\
\hline & & Pusat Perbelanjaan & 120 & $300 \times 500$ & $400 \times 400$ \\
\hline & & Tempat Ibadah & - & - & - \\
\hline & \multirow{3}{*}{ Dua Arah } & Kantor & 80 & $300 \times 600$ & $500 \times 500$ \\
\hline & & Pusat Perbelanjaan & 80 & $300 \times 500$ & $400 \times 400$ \\
\hline & & Tempat Ibadah & - & - & - \\
\hline
\end{tabular}

Dari Tabel 9 telihat bahwa didapatkan hasil komposisi dimensi-dimensi komponen struktur bangunan sebagai berikut :

1. Bangunan SatuTingkat

a. Pelat satu arah

1) Bangunan kantor : 
a) Pelat $120 \mathrm{~mm}$, balok induk 300x600 mm, balok anak 250x550 mm dan kolom 500x500 mm

b) Pelat $160 \mathrm{~mm}$, balok induk 300x500 mm, balok anak 250x550 mm dan kolom 500x500 mm

2) Bangunan pusat perbelanjaan :

a) Pelat $120 \mathrm{~mm}$, balok induk 300x600 mm, balok anak 250x550 mm dan kolom 500x500 mm

b) Pelat $160 \mathrm{~mm}$, balok induk 300x500 mm, balok anak 250x550 mm dan kolom 500x500 mm

c) Pelat $160 \mathrm{~mm}$, balok induk $300 \times 600 \mathrm{~mm}$, balok anak 250x550 mm dan kolom 400x400 mm

3) Bangunan Tempat Ibadah : Pelat $160 \mathrm{~mm}$, balok induk 300x600 mm, balok anak 250x550 mm dan kolom 600x600 mm

b. Pelat dua arah

1) Bangunan kantor :

a) Pelat $80 \mathrm{~mm}$, balok induk $300 \times 600 \mathrm{~mm}$, balok anak 250x550 mm dan kolom 500x500 mm

b) Pelat $160 \mathrm{~mm}$, balok induk $300 \times 500 \mathrm{~mm}$, balok anak 250x550 mm dan kolom 500x500 mm

2) Bangunan pusat perbelanjaan :

a) Pelat $80 \mathrm{~mm}$, balok induk 300x600 mm, balok anak 250x550 mm dan kolom 500x500 mm

b) Pelat $120 \mathrm{~mm}$, balok induk 300x500 mm, balok anak 250x550 mm dan kolom 500x500 mm

c) Pelat $120 \mathrm{~mm}$, balok induk 300x600 mm, balok anak 250x550 mm dan kolom 400x400 mm

3) Bangunan Tempat Ibadah : Pelat $120 \mathrm{~mm}$, balok induk 300x600 mm, balok anak 250x550 mm dan kolom 600x600 mm

\section{Bangunan Satu Tingkat}

2. Pelat Satu Arah Bangunan Satu Tingkat

Pengaruh Getaran Pada Struktur Bangunan Satu Tingkat Akibat Gerakan Manusia

(Dwi Catra Rimaza, Daud Rachmat Wiyono) 
Tabel 10. Persentase Selisih $a_{0} / g$ dengan $a_{p} / g P e l a t ~ S a t u$ Arah Bangunan Satu Tingkat, Variasi Tebal Pelat.

\begin{tabular}{|c|c|c|c|c|}
\hline \multirow{2}{*}{ Model 1 } & $\begin{array}{c}\text { Tebal Pelat } \\
(\mathbf{m m})\end{array}$ & Kantor & $\begin{array}{c}\text { Pusat } \\
\text { Perbelanjaan }\end{array}$ & $\begin{array}{c}\text { Tempat } \\
\text { Ibadah }\end{array}$ \\
\hline \multirow{3}{*}{$\mathbf{a}_{\mathbf{0}} / \mathbf{g}(\mathbf{\%})$} & 120 & & & \\
\cline { 2 - 5 } & 140 & 0.5 & 1.5 & 0.5 \\
\cline { 2 - 5 } & 160 & & & \\
\hline \multirow{3}{*}{$\mathbf{a}_{\mathbf{p}} / \mathbf{g}(\mathbf{\%})$} & 120 & 0.388 & 0.582 & 0.582 \\
\cline { 2 - 5 } & 140 & 0.387 & 0.581 & 0.581 \\
\cline { 2 - 5 } Persentase \\
$\begin{array}{c}\text { selisih } \mathbf{a}_{\mathbf{0}} / \mathbf{g} \\
\text { dengan } \mathbf{a}_{\mathbf{p}} / \mathbf{g}\end{array}$ & 160 & 0.385 & 0.578 & 0.578 \\
\cline { 2 - 5 } & 120 & 22.413 & 61.207 & -16.380 \\
\cline { 2 - 5 } & 140 & 22.591 & 61.296 & -16.113 \\
\hline
\end{tabular}

Tabel 11. Persentase Selisih $\mathbf{a}_{0} / g$ dengan $a_{p} / g$ Pelat Satu Arah Bangunan Satu Tingkat, Variasi Dimensi Balok Induk

\begin{tabular}{|c|c|c|c|c|}
\hline Model 2 & $\begin{array}{c}\text { Dimensi } \\
\text { Balok (mm) }\end{array}$ & Kantor & $\begin{array}{c}\text { Pusat } \\
\text { Perbelanjaan }\end{array}$ & $\begin{array}{c}\text { Tempat } \\
\text { Ibadah }\end{array}$ \\
\hline \multirow{3}{*}{$\mathbf{a}_{\mathbf{0}} / \mathbf{g}(\%)$} & $300 \times 500$ & & & \\
\cline { 2 - 5 } & $300 \times 600$ & 0.5 & 1.5 & 0.5 \\
\cline { 2 - 5 } & $300 \times 700$ & & & \\
\hline \multirow{3}{*}{$\mathbf{a}_{\mathbf{p}} / \mathbf{g}(\%)$} & $300 \times 500$ & 0.445 & 0.668 & 0.668 \\
\cline { 2 - 5 } & $300 \times 600$ & 0.385 & 0.578 & 0.578 \\
\hline \multirow{2}{*}{$\begin{array}{c}\text { Persentase } \\
\text { selisih } \mathbf{a}_{\mathbf{0}} / \mathbf{g} \\
\text { dengan } \mathbf{a}_{\mathbf{p}} / \mathbf{g}\end{array}$} & $300 \times 700$ & 0.343 & 0.514 & 0.514 \\
\cline { 2 - 5 } & $300 \times 500$ & 10.959 & 55.480 & -33.561 \\
\hline \multirow{2}{*}{} & $300 \times 600$ & 22.943 & 61.472 & -15.585 \\
\hline
\end{tabular}

Tabel 12. Persentase Selisih $a_{0} / g$ dengan $a_{p} / g$ Pelat Satu Arah Bangunan Satu Tingkat, Variasi Dimensi Kolom

\begin{tabular}{|c|c|c|c|c|}
\hline \multirow{2}{*}{ Model 3 } & $\begin{array}{c}\text { Dimensi } \\
\text { Kolom } \\
(\mathbf{m m})\end{array}$ & Kantor & $\begin{array}{c}\text { Pusat } \\
\text { Perbelanjaan }\end{array}$ & $\begin{array}{c}\text { Tempat } \\
\text { Ibadah }\end{array}$ \\
\hline \multirow{3}{*}{$\mathbf{a}_{\mathbf{0}} / \mathbf{g}(\%)$} & $400 \times 400$ & & & \\
\cline { 2 - 3 } & $500 \times 500$ & 0.5 & 1.5 & 0.5 \\
\cline { 2 - 5 } & $600 \times 600$ & & 0.948 & 0.948 \\
\hline \multirow{3}{*}{$\mathbf{a}_{\mathbf{p}} / \mathbf{g}(\%)$} & $400 \times 400$ & 0.632 & 0.578 & 0.578 \\
\cline { 2 - 5 } & $500 \times 500$ & 0.385 & 0.356 & 0.356 \\
\cline { 2 - 5 } & $600 \times 600$ & 0.237 & 0.250 \\
\hline
\end{tabular}




\begin{tabular}{|c|c|c|c|c|}
\hline \multicolumn{5}{|c|}{ Tabel 12. Lanjutan. } \\
\hline \multirow{2}{*}{$\begin{array}{c}\text { Persentase } \\
\text { selisih } \mathbf{a}_{\mathbf{0}} / \mathbf{g} \\
\text { dengan } \mathbf{a}_{\mathbf{p}} / \mathbf{g}\end{array}$} & $400 \times 400$ & -26.385 & 36.808 & -89.577 \\
\cline { 2 - 5 } & $500 \times 500$ & 22.943 & 61.472 & -15.585 \\
\cline { 2 - 5 } & $600 \times 600$ & 52.552 & 76.276 & 28.829 \\
\hline
\end{tabular}

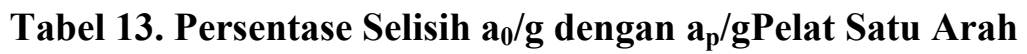
Bangunan Satu Tingkat

\begin{tabular}{|l|c|c|c|c|}
\hline \multirow{2}{*}{} & \multirow{2}{*}{ Dimensi (mm) } & \multicolumn{3}{|c|}{ Persentase selisih $\mathbf{a}_{\mathbf{0}} / \mathbf{g}$ dengan $\mathbf{a}_{\mathbf{p}} / \mathbf{g}$} \\
\cline { 2 - 5 } & & Kantor & Pusat Perbelanjaan & Tempat Ibadah \\
\hline \multirow{3}{*}{ Model 1 } & 120 & 22.413 & 61.207 & -16.380 \\
\cline { 2 - 5 } & 140 & 22.591 & 61.296 & -16.113 \\
\cline { 2 - 5 } & 160 & 22.964 & 61.482 & -15.555 \\
\hline \multirow{3}{*}{ Model 2 } & $300 \times 500$ & 10.959 & 55.480 & -33.561 \\
\cline { 2 - 5 } & $300 \times 600$ & 22.943 & 61.472 & -15.585 \\
\cline { 2 - 5 } & $300 \times 700$ & 31.407 & 65.704 & -2.889 \\
\hline \multirow{3}{*}{ Model 3 } & $400 \times 400$ & -26.385 & 36.808 & -89.577 \\
\cline { 2 - 5 } & $500 \times 500$ & 22.943 & 61.472 & -15.585 \\
\cline { 2 - 5 } & $600 \times 600$ & 52.552 & 76.276 & 28.829 \\
\hline
\end{tabular}

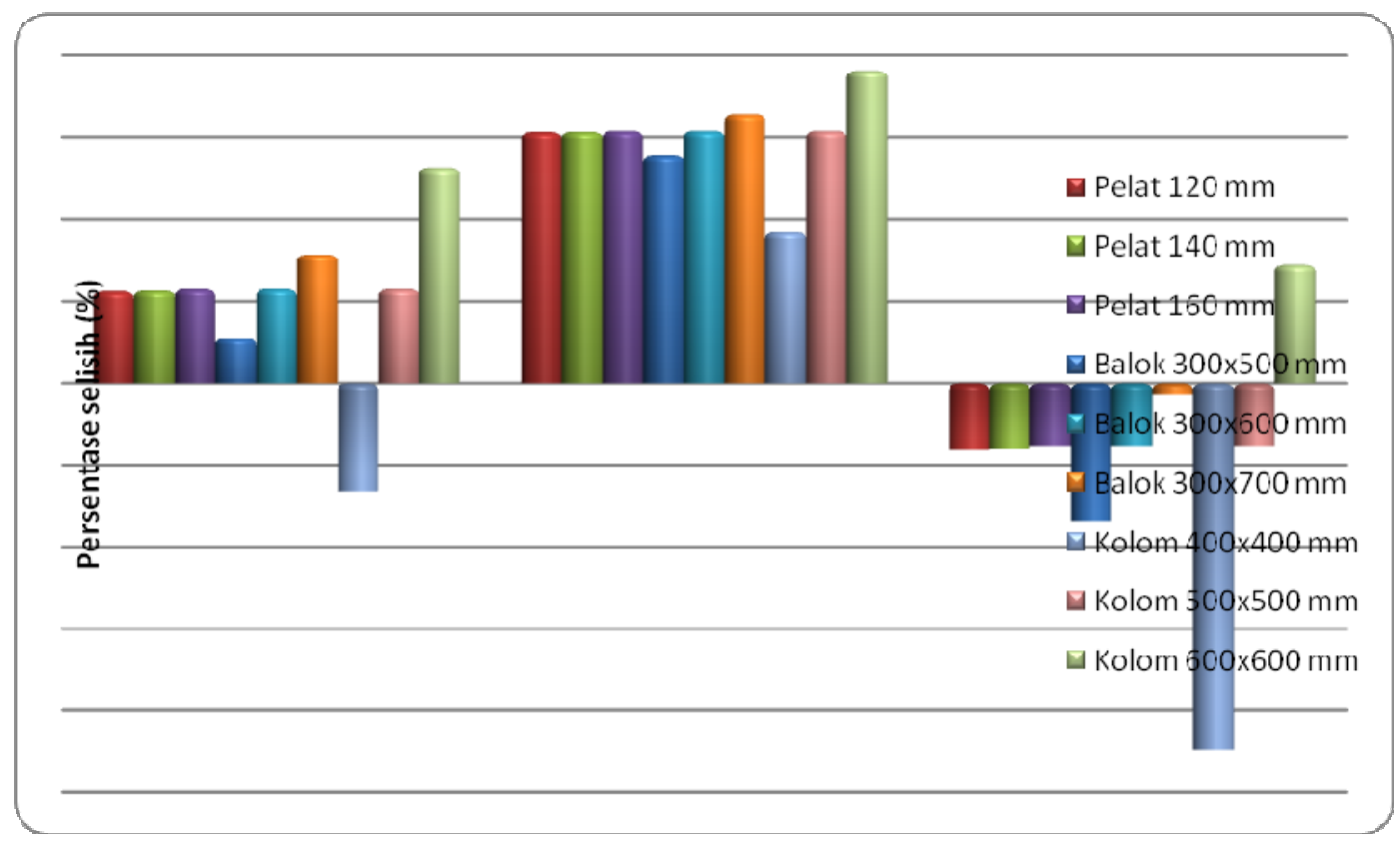

Gambar 6. Diagram Persentase selisih $a_{0} / g$ dengan $a_{p} / g$ Pelat Satu Arah Bangunan Satu Tingkat. 
3. Pelat Dua Arah Bangunan Satu Tingkat

Tabel 14. Persentase Selisih $a_{0} / g$ dengan $a_{p} / g$ Pelat Dua Arah Bangunan Satu Tingkat, Variasi Tebal Pelat.

\begin{tabular}{|c|c|c|c|c|}
\hline Model 1 & $\begin{array}{c}\text { Tebal Pelat } \\
(\mathbf{m m})\end{array}$ & Kantor & $\begin{array}{c}\text { Pusat } \\
\text { Perbelanjaan }\end{array}$ & $\begin{array}{c}\text { Tempat } \\
\text { Ibadah }\end{array}$ \\
\hline \multirow{2}{*}{$\mathbf{a}_{\mathbf{0}} / \mathbf{g}(\%)$} & 80 & & & \\
\cline { 2 - 5 } & 100 & 0.5 & 1.5 & 0.5 \\
\cline { 2 - 5 } & 120 & 0.387 & 0.581 & 0.581 \\
\cline { 2 - 5 } $\mathbf{a}_{\mathbf{p}} / \mathbf{g}(\mathbf{\%})$ & 100 & 0.388 & 0.582 & 0.582 \\
\cline { 2 - 5 } & 120 & 0.388 & 0.582 & 0.582 \\
\hline $\begin{array}{c}\text { Persentase } \\
\text { selisih } \mathbf{a}_{\mathbf{0}} / \mathbf{g} \\
\mathbf{d e n g a n} \\
\mathbf{a}_{\mathbf{p}} / \mathbf{g}\end{array}$ & 100 & 22.516 & 61.258 & -16.226 \\
\cline { 2 - 5 } & 120 & 22.346 & 61.173 & -16.481 \\
\hline
\end{tabular}

Tabel 15. Persentase Selisih $\mathbf{a}_{0} / g$ dengan $a_{p} / g$ Pelat Dua Arah Bangunan Satu Tingkat, Variasi Dimensi Balok Induk.

\begin{tabular}{|c|c|c|c|c|}
\hline Model 2 & $\begin{array}{c}\text { Dimensi } \\
\text { Balok } \\
(\mathbf{m m})\end{array}$ & Kantor & $\begin{array}{c}\text { Pusat } \\
\text { Perbelanjaan }\end{array}$ & $\begin{array}{c}\text { Tempat } \\
\text { Ibadah }\end{array}$ \\
\hline \multirow{2}{*}{$\mathbf{a}_{\mathbf{0}} / \mathbf{g}(\%)$} & $300 \times 500$ & & & \\
\cline { 2 - 5 } & $300 \times 600$ & 0.5 & 1.5 & 0.5 \\
\cline { 2 - 5 } & $300 \times 700$ & & 0.675 & 0.675 \\
\hline \multirow{2}{*}{$\mathbf{a}_{\mathbf{p}} / \mathbf{g}(\%)$} & $300 \times 500$ & 0.450 & 0.582 & 0.582 \\
\cline { 2 - 5 } & $300 \times 600$ & 0.388 & 0.459 & 0.459 \\
\cline { 2 - 5 } & $300 \times 700$ & 0.306 & 54.986 & -35.042 \\
\hline $\begin{array}{c}\text { Persentase } \\
\text { selisih } \mathbf{a}_{\mathbf{0}} / \mathbf{g} \\
\text { dengan } \\
\mathbf{a}_{\mathbf{p}} / \mathbf{g}\end{array}$ & $300 \times 500$ & 9.972 & 61.228 & -16.315 \\
\cline { 2 - 5 } & $300 \times 600$ & 22.457 & 69.395 & 8.184 \\
\hline
\end{tabular}

Tabel 16. Persentase Selisih $a_{0} / g$ dengan $a_{p} / g$ Pelat Dua Arah Bangunan Satu Tingkat, Variasi Dimensi Kolom.

\begin{tabular}{|c|c|c|c|c|}
\hline \multirow{2}{*}{ Model 3 } & $\begin{array}{c}\text { Dimensi } \\
\text { Kolom } \\
(\mathbf{m m})\end{array}$ & Kantor & $\begin{array}{c}\text { Pusat } \\
\text { Perbelanjaan }\end{array}$ & $\begin{array}{c}\text { Tempat } \\
\text { Ibadah }\end{array}$ \\
\hline \multirow{3}{*}{$\mathbf{a}_{\mathbf{0}} / \mathbf{g}(\%)$} & $400 \times 400$ & & & \\
\cline { 2 - 2 } & $500 \times 500$ & 0.5 & 1.5 & 0.5 \\
\cline { 2 - 3 } & $600 \times 600$ & & & \\
\hline
\end{tabular}




\begin{tabular}{|c|c|c|c|c|}
\hline \multicolumn{5}{|c|}{ Tabel 16. Lanjutan. } \\
\hline \multirow{3}{*}{$\mathbf{a}_{\mathbf{p}} / \mathbf{g}(\%)$} & $400 \times 400$ & 0.651 & 0.977 & 0.977 \\
\cline { 2 - 5 } & $500 \times 500$ & 0.388 & 0.582 & 0.582 \\
\cline { 2 - 5 } & $600 \times 600$ & 0.234 & 0.351 & 0.351 \\
\hline $\begin{array}{c}\text { Persentase } \\
\text { selisih } \mathbf{a}_{\mathbf{0}} / \mathbf{g} \\
\text { dengan } \\
\mathbf{a}_{\mathbf{p}} / \mathbf{g}\end{array}$ & $400 \times 400$ & -30.257 & 34.872 & -95.385 \\
\cline { 2 - 5 } & $500 \times 500$ & 22.457 & 61.228 & -16.315 \\
\cline { 2 - 5 } & $600 \times 600$ & 53.250 & 76.625 & 29.875 \\
\hline
\end{tabular}

Tabel 17. Persentase selisih $a_{0} / g$ dengan $a_{p} / g$ Pelat Dua Arah Bangunan Satu Tingkat.

\begin{tabular}{|c|c|c|c|c|}
\hline \multirow{2}{*}{} & \multirow{2}{*}{ Dimensi (mm) } & \multicolumn{3}{|c|}{ Persentase selisih $\mathbf{a}_{\mathbf{0}} / \mathbf{g}$ dengan $\mathbf{a}_{\mathbf{p}} / \mathbf{g}$} \\
\cline { 2 - 5 } & & Kantor & Pusat Perbelanjaan & Tempat Ibadah \\
\hline \multirow{3}{*}{ Model 1 } & 80 & 22.516 & 61.258 & -16.226 \\
\cline { 2 - 5 } & 100 & 22.346 & 61.173 & -16.481 \\
\cline { 2 - 5 } & 120 & 22.457 & 61.228 & -16.315 \\
\hline \multirow{3}{*}{ Model 2 } & $300 \times 500$ & 9.972 & 54.986 & -35.042 \\
\cline { 2 - 5 } & $300 \times 600$ & 22.457 & 61.228 & -16.315 \\
\cline { 2 - 5 } Model 3 & $300 \times 700$ & 38.789 & 69.395 & -9.184 \\
\cline { 2 - 5 } & $400 \times 400$ & -30.257 & 34.872 & -16.315 \\
\cline { 2 - 5 } & $500 \times 500$ & 22.457 & 61.228 & 29.875 \\
\hline
\end{tabular}

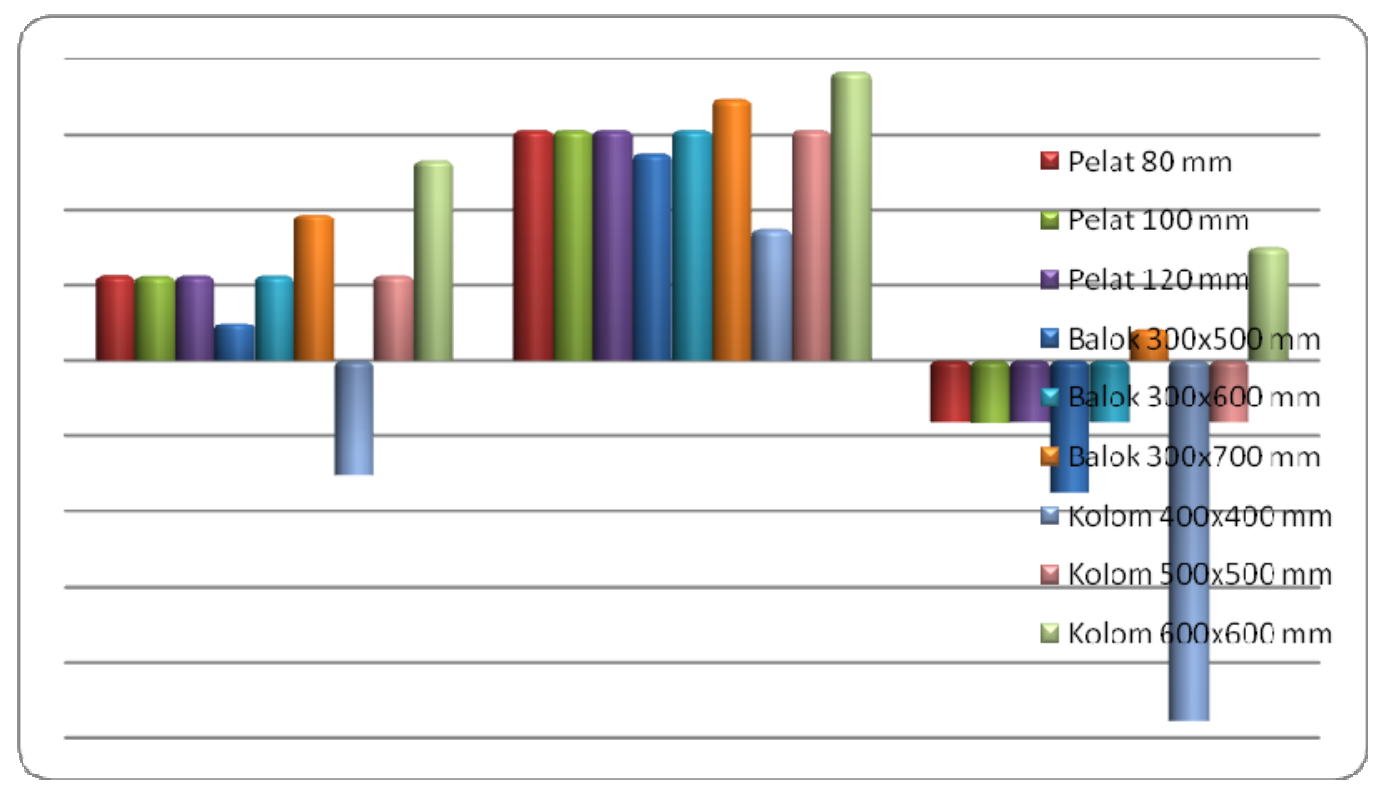

Gambar 7. Diagram Persentase selisih $a_{0} / g$ dengan $a_{p} / g$ Pelat Dua Arah Bangunan Satu Tingkat

Pengaruh Getaran Pada Struktur Bangunan Satu Tingkat Akibat Gerakan Manusia 
Hasil analisis memperlihatkan bahwa perubahan dimensi pada pelat mengakibatkan nilai persentase selisih $\mathrm{a}_{0} / \mathrm{g}$ dengan $\mathrm{a}_{\mathrm{p}} / \mathrm{g}$ tidak mengalami perubahan yang signifikan pada ketiga bangunan tersebut. Berbeda dengan perubahan dimensi pada balok induk dan kolom, perubahan keduanya mengakibatkan nilai persentase selisih $\mathrm{a}_{0} / g$ dengan $\mathrm{a}_{\mathrm{p}} / \mathrm{g}$ mengalami perubahan yang cukup signifikan pada ketiga bangunan tersebut.

\section{KESIMPULAN DAN SARAN}

\subsection{Kesimpulan}

Berdasarkan hasil analisis dari berbagai macam model dengan berbagai macam variasi ukuran dimensi komponen elemen struktur yang ada, didapatkan beberapa kesimpulan, antar lain :

1. Diantara variasi pada dimensi pelat, balok induk, dan kolom pada semua model, perubahan dimensi komponen struktur yang paling berpengaruh terhadap besarnya nilai persentase selisih dengan persyaratan batas dan keoptimalan desain suatu bangunan adalah perubahan pada dimensi kolom.

2. Nilai persentase selisih antara perkiraan puncak percepatan dengan batas puncak percepatan berubah sangat signifikan seiring dengan perubahan pada dimensi kolom, sedangkan perubahan pada dimensi pelat dan balok induk tidak menghasilkan perubahan yang signifikan pada nilai persentase selisih dari perkiraan puncak percepatan dengan batas puncak percepatan.

3. Desain bangunan pusat perbelanjaan seluruhnya memenuhi syarat batas kelayakan dan kenyamanan getaran, sedangkan untuk bangunan kantor, ada beberapa model yang tidak memenuhi syarat batas kelayakan dan kenyamanan getaran, dan untuk bangunan tempat ibadah hampir pada seluruh model tidak memenuhi syarat batas kelayakan dan kenyamanan getaran.

\subsection{Saran}

Adapun beberapa saran yang sebaiknya dilakukan lebih lanjut dari tulisan ini, antara lain : 
1. Sebaiknya dilakukan penelitian lebih lanjut untuk pemodelan denah yang lebih luas, karena pada tulisan ini ini hanya dilakukan pemodelan untuk satu bentang saja.

2. Sebaiknya dilakukan penelitian lebih lanjut untuk pemodelan bangunan dengan tingkat bangunan yang lebih tinggi karena pada tulisan ini hanya dilakukan pemodelan untuk gedung satu tingkat saja.

\section{DAFTAR PUSTAKA}

1. Bachmann, H. and Walter, A. (1987), Vibration in Structures Induced by Man and Machines,Zurich : International Association for Bridge and Structural Engineering.

2. Bungey, J.H. and Mosley, W.H. (1987), Reinforced concrete design, $3^{\text {rd }}$ edition, London : The Macmillan Press Ltd.

3. Departemen Pekerjaan Umum (1987), Pedoman Perencanaan Pembebanan untuk Rumah dan Gedung, SKBI-1.3.53.1987.UDC : 624.042.

4. Dipohusodo, Istimawan. (1999), Struktur Beton Bertulang "Berdasarkan SK SNI T-15-1991-03 Departemen Pekerjaan Umum RI”, Jakarta : Gramedia Pustaka Utama.

5. McCormac, J.C. (2001), Design of Renforced Concrete, $5^{\text {th }}$ Edition, John Wiley and Sons, Inc.

6. Nawy, Edward,G. (2005), Reinforced Concrete “a Fundamental Approach”, $5^{\text {th }}$ Edition, New Jersey : Pearson Education, Inc.

7. Nilson, AH. and Winter,George. (1993), Perencanaan Struktur Beton Bertulang, Jakarta : PT. Pradnya Paramita.

8. Paz, Mario (1985), Structural Dinamics “Theory and Computation”, $2^{\text {nd }}$ Edition, Van Nostrand Reinhold Com, Inc.

9. Salmon, Charles, G. and Wang, Chu-Kia.(1985), Reinforced Concrete Design, $4^{\text {th }}$ edition, Harper and Row, Inc.

10. S.K. Sidharta dkk (1999), "Struktur beton", Semarang : Universitas Semarang, ISBN.979-9156-22-X 
11. Steel Design Guide Series $11^{\text {th }}$ (2003), "Floor Vibration Due to Human Activity”. USA : American Institute of Steel Construction.

12. Standar Nasional Indonesia, 2002. SNI 03-2847-2002 Tata Cara Perencanaan Struktur Beton untuk Bangunan Gedung, Standar Nasional Indonesia. 